\title{
Deoxycholic acid induces the overexpression of intestinal mucin, MUC2, via NF-kB signaling pathway in human esophageal adenocarcinoma cells
}

\author{
JianTao $\mathrm{Wu}^{\dagger}$, Jun Gong*†, Juan Geng ${ }^{\dagger}$ and YinXue Song ${ }^{\dagger}$
}

Address: Department of Gastroenterology, the Second Affiliated Hospital, Xi'an Jiaotong University School of Medicine, Xi'an, Shaanxi, 710004, PR China

Email: JianTao Wu - wujjtt@gmail.com; Jun Gong* - jungong2@gmail.com; Juan Geng - gengjuan1@gmail.com;

YinXue Song - songyinxue2@gmail.com

* Corresponding author †Equal contributors

Published: 13 November 2008

BMC Cancer 2008, 8:333 doi:10.1 186/147/-2407-8-333

This article is available from: http://www.biomedcentral.com/I47/-2407/8/333

(C) 2008 Wu et al; licensee BioMed Central Ltd.

This is an Open Access article distributed under the terms of the Creative Commons Attribution License (http://creativecommons.org/licenses/by/2.0), which permits unrestricted use, distribution, and reproduction in any medium, provided the original work is properly cited.
Received: 16 July 2008

Accepted: 13 November 2008

\begin{abstract}
Background: Mucin alterations are a common feature of esophageal neoplasia, and alterations in MUC2 mucin have been associated with tumor progression in the esophagus. Bile acids have been linked to esophageal adenocarcinoma and mucin secretion, but their effects on mucin gene expression in human esophageal adenocarcinoma cells is unknown.
\end{abstract}

Methods: Human esophageal adenocarcinoma cells were treated 18 hours with 50-300 $\mu \mathrm{M}$ deoxycholic acid, chenodeoxycholic acid, or taurocholic acid. MUC2 transcription was assayed using a MUC2 promoter reporter luciferase construct and MUC2 protein was assayed by Western blot analysis. Transcription Nuclear factor- $\mathrm{KB}$ activity was measured using a Nuclear factor- $\mathrm{KB}$ reporter construct and confirmed by Western blot analysis for Nuclear factor- $\kappa B$ p 65 .

Results: MUC2 transcription and MUC2 protein expression were increased four to five fold by bile acids in a time and dose-dependent manner with no effect on cell viability. Nuclear factor- $\kappa B$ activity was also increased. Treatment with the putative chemopreventive agent aspirin, which decreased Nuclear factor- $\kappa B$ activity, also decreased MUC2 transcription. Nuclear factor- $\kappa B$ p 65 siRNA decreased MUC2 transcription, confirming the significance of Nuclear factor- $\kappa B$ in MUC2 induction by deoxycholic acid. Calphostin C, a specific inhibitor of protein kinase $C$ (PKC), greatly decreased bile acid induced MUC2 transcription and Nuclear factor- $\mathrm{KB}$ activity, whereas inhibitors of MAP kinase had no effect.

Conclusion: Deoxycholic acid induced MUC2 overexpression in human esophageal adenocarcinoma cells by activation of Nuclear factor- $\kappa B$ transcription through a process involving PKC-dependent but not PKA, independent of activation of MAP kinase.

\section{Background}

Changes in the characteristics of the surface epithelial mucins is the hallmark of Barrett's metaplasia, dysplasia and adenocarcinoma of esophagus[1,2]. MUC2, a high molecular weight glycoprotein, is the major secreted mucin in the large and small intestine[3,4]. Human esophageal adenocarcinoma and cell lines derived from tumors can differ significantly in the amount of MUC2 
mucin synthesized and these differences correlate with altered biochemical and biologic properties including those with relevance to invasion and metastasis, MUC2 is expressed in esophageal carcinoma cell lines, and patients with esophageal carcinomas characteristically present with advanced-stage disease[1,5,6].

Bile acids, fractions of duodenogastricoesophageal reflux (DGER) have been detected in patients with extensive esophageal mucosal damage, have been reported to promote esophageal carcinogenesis $[7,8]$. These bile acids, primarily deoxycholic acid (DCA), are cytotoxic to esophageal cells[8], and are established tumor promoters in animal models[9]. In esophageal adenocarcinoma, DCA is believed to contribute to carcinogenesis during reflux where reluxates enter the lower esophagus[10]. Bile acids also have been reported to stimulate invasion and metastasis of esophageal carcinoma cells via activation of multiple signaling pathways [11-13]. Although regulations of MUC1 and MUC4 mucin genes by bile acids, such as DCA, CDCA and TCA, in human oesophageal cancer cells have been the thorough extensive study [14-16], the mechanisms responsible for regulation of MUC2 expression in the esophageal adenocarcinoma cells remain unknown.

In the current study, we sought to determine the effects of bile acids on MUC2 gene expression in esophageal adenocarcinoma cells and the molecular mechanisms involved. We find that bile acids induce MUC2 expression in human esophageal adenocarcinoma cells at the level of transcription through a process that involves protein kinase C (PKC)-dependent activation of Nuclear factor- $\kappa B$ $(\mathrm{NF}-\kappa \mathrm{B})$, primarily a MAP kinase-independent.

\section{Methods \\ Materials}

Deoxycholic acid (DCA), chenodeoxycholic acid (CDCA), and taurocholic acid (TCA) were obtained from Sigma (St. Louis, USA). CAPE, Calphostin C, U0126 (1,4-diamino-2, 3-dicyano-1,4-bis(2-aminophenylthio)butadiene),

PD98059 (2'-amino-3'-methoxyflavone), and H-8 (PKA inhibitor) ( $\mathrm{N}$-[2-(methylamino)ethyl]-5-isoquinolinesulfonamide dihydrochloride) were purchased from Calbiochem (San Diego, CA). Mouse monoclonal antibody (MoAb) CCP-58, specific for MUC2 glycoprotein, was obtained from Novocastra (Newcastle, UK). Antibodies for Nuclear factor- $\kappa \mathrm{B}(\mathrm{NF}-\kappa \mathrm{B}) \mathrm{p} 65$, extracellular signalregulated kinase (ERK1/2), JNK, P38 and phospho-ERK1/ 2, JNK, P38 were obtained from Cell Signaling Technology (Beverly, MA), aspirin, secondary antibodies and antibeta-actin MoAb was obtained from Sigma (USA). FuGENE 6 transfection reagent was from Roche (Indianapolis, IN).

\section{Cell Culture and Treatment}

SEG-1 is a BE adenocarcinoma cell line, the cell line were cultured in Dulbecco's Modified Eagle Medium (Invitrogen, Carlsbad, Calif) supplemented with 10\% heat-inactivated fetal bovine serum (Invitrogen) and $100 \mathrm{U} / \mathrm{mL}$ penicillin $\mathrm{G}$ and $100 \mu \mathrm{g} / \mathrm{mL}$ streptomycin (Invitrogen) at $37^{\circ} \mathrm{C}$ in a humidified incubator containing $5 \%$ carbon dioxide.

SEG-1 cells were plated in regular medium for 36 hours. The medium was then replaced with $0.5 \%$ FBS for an additional 24 hours. Cultures were then treated with bile acids. For inhibitor assays, SEG-1 cells were pretreated with inhibitors for 1 hour before exposure to DCA for an additional 18 hours. Calphostin $\mathrm{C}$ was used under a fluorescent lamp of $13 \mathrm{~W}$ located $15 \mathrm{~cm}$ above the plates.

For determining the effects of bile acids on viability, cells were treated for 24 hours with $\leq 200 \mu \mathrm{M}$ DCA, CDCA, or TCA, then detected with The CellTiter-Fluor ${ }^{\mathrm{TM}}$ Assay kit(Promega BioSciences, San Luis Obispo, CA), according to the manufacturer's protocol

\section{Protein Extraction and Western Blotting}

Cellular proteins from treated SEG-1 cells were prepared in $40 \mathrm{mM}$ Tris-HCI, pH 6.9, $150 \mathrm{mM} \mathrm{NaCl}, 2 \mathrm{mM}$ ethylenediaminetetraacetic acid, $100 \mathrm{mM}$ sodium fluoride, 10 $\mathrm{mM}$ sodium pyrophosphate, $2 \mathrm{mM}$ orthovanadate, $1 \%$ Triton X-100, 1\% Nonidert P40 (NP-40), 0.3 mM phenylmethanesulfonyl fluoride, and $1 \mathrm{mini}$ tablet protein inhibitor (sigma, USA). Separate cytosol and nuclear protein lysates were prepared by using the Active Motif Nuclear Extract Kit (Active Motif Europe, Rixensart, Belgium), according to the manufacturer's protocol. For routine quantitation of proteins, following the manufacturer's protocol (Pierce, Rockford, IL). Equal amounts of protein samples were subjected to sodium dodecyl sulfate-polyacrylamide gel electrophoresis on either 3-8\% Tris-acetate gradient gels for MUC2 detection or $10 \%$ Tris-glycine gels for detection of other proteins. After gel electrophoresis and transfer to nitrocellulose, the membranes were stained in $0.5 \%$ Ponceau $\mathrm{S}$ with $1 \%$ acetic acid to confirm the equal loading and transfer efficiency. Membranes were incubated at $4^{\circ} \mathrm{C}$ overnight in a blocking solution containing $5 \%$ bovine skim milk and $0.1 \%$ Tween 20 (Fischer Scientific, Pittsburgh, PA) in TBS (10 mM Tris- $\mathrm{HCl}$ with $150 \mathrm{mM} \mathrm{NaCl}, \mathrm{pH}$ 7.6), then probed with specific primary and secondary antibodies conjugated to horseradish peroxidase. Immunoreactive bands were visualized by chemiluminescence solution and exposure to X-ray film.

\section{RNA Isolation and RT-PCR}

Total RNA was isolated using TriReagent (Molecular Research Center Inc.), and $3 \mu \mathrm{g}$ was primed with random 
hexamers and reverse transcribed using Superscript II (Invitrogen) in a final volume of $50 \mu \mathrm{l}$. One microliter of this mixture was PCR-amplified in a $10 \mu \mathrm{l}$ reaction using AmpliTaq DNA polymerase (Applied Biosystems) with the addition of 5\% dimethyl sulfoxide. Primers for MUC2 were (forward) 5'-TGC CTG GCC CTG TCT TTG-3' and (reverse) 5'-CAG CTC CAG CAT GAG TGC-3'; NF- $\kappa B$ p65 were (forward) 5'-GCG AGA GGA GCA CAG ATA CC-3' and (reverse) $5^{\prime}$-CTG ATA GCC TGC TCC AGG TC-3'. The PCR reaction mixture was denatured at $95^{\circ} \mathrm{C}$ for $5 \mathrm{~min}$ followed by 30 cycles at $93^{\circ} \mathrm{C}$ for $30 \mathrm{~s}, 60^{\circ} \mathrm{C}$ for $30 \mathrm{~s}$, and $72^{\circ} \mathrm{C}$ for $30 \mathrm{~s}$. Alternatively, blocked and unblocked primers for beta-actin (forward) 5'-ATC TGG CAC CAC ACC TTC TAC AAT GAG CTG C-3'; (reverse) 5'-CGT CAT ACT CCT GCT TGC TGA TCC ACA TCT G-3' were used to amplify this message as an internal control. All the primers were synthesized by Sangon (Shanghai, China). All PCR products were analysed by Gel-Pro analyser version 3.1 software.

\section{Transient Transfection and Luciferase Reporter Assays}

Plasmids were prepared using the Genopure plasmid midi kit from Roche (Indianapolis, IN). Methods to measure the MUC2 promoter activity with luciferase as a reporter have been reported previously [17-19]. Upstream fragments of 2665 base pair (bp) from immediately adjacent to the 5' translation start site of human MUC2 [GenBank accession number U67167] [17] were generated by routine polymerase chain reaction from human genomic DNA, using the following primer pairs (forward) 5'-GAGGCTAGCCCGGGCTTCCTGGTGAGTC-3', and (reverse) 5'-GAGCTCGAGCATGGTGGCTGGCAGGGGC-3'. The 2665-bp fragment was then inserted upstream of the luciferase reporter in the pGL3-basic vector, according to the instructions provided by the manufacturer (Promega). DNA sequencing was performed to verify the correct clone.

NF- $\mathrm{B}$ transient transfection assays have been reported previously $[20,21]$. The cells were transfected using the SuperFect reagent (Qiagen) with a NF- $k B$ luciferase reporter (Clontech) plasmid and a SV40 promoter-driven beta-galactosidase expression plasmid to normalize the transfection efficiency. After additional $24 \mathrm{~h}$, the cells were harvested in phosphate-buffered saline, lysed in luciferase lysis buffer (Promega), and assayed for luciferase and beta-galactosidase activities using the Promega luciferase assay system (Promega).

For transient transfection, SEG-1 cells were seeded at a concentration of $6 \times 10^{5}$ cells per well in 6 -well plates. After overnight, the cells in each well were transfected with DNA $(3 \mu \mathrm{g}$ of $M U C 2$ or NF- $\kappa B$-luciferase reporter plasmid and $0.2 \mu \mathrm{g}$ of $\mathrm{pCH} 110$ ) by using $3 \mu \mathrm{L}$ of FuGENE6 (Roche) by following the manufacturer's proto- col. After a 24-hour exposure to the transfection mixture, the cells were incubated in medium containing $10 \%$ FBS and different concentrations of bile acids or inhibitors for an additional 18 hours and then harvested for measurement of beta-galactosidase activity and luciferase activity. The latter was measured by using the Promega luciferase assay system according to the manufacturer's protocol using a TriStar LB941 (Berthold; Germany). Luciferase was normalized to the beta-galactosidase activity to account for differences in transfection efficiency.

\section{NF- $\kappa$ B p65 siRNA Transfection}

SignalSilence NF-кB p65 siRNA was purchased from Cell Signaling Technology (Danvers, MA). siCONTROL nontargeting siRNA purchased from Dharmacon (Chicago, IL) was used as a control siRNA. Cells were transfected with siRNA using Oligofectamine transfection reagent (Invitrogen) for $72 \mathrm{~h}$ according to the manufacturer's instructions. To confirm the efficacy of NF- $\kappa B$ p 65 siRNA, NF- $\kappa$ B p 65 mRNA and protein were analyzed using RTPCR and Western Blotting. The cytotoxic effect of NF- $\mathrm{KB}$ p65 siRNA on SEG-1 cells was determined by CellTiterFluor $^{\mathrm{TM}}$ Assay (Promega, Madison, WI) according to the manufacturer's protocol.

\section{Statistical Analyses}

Results were expressed as means $\pm \mathrm{SD}$, and statistical significance was determined using by ANOVA. Differences of $\mathrm{P}<0.05$ were considered significant. All experiments were performed in triplicate.

\section{Results \\ Effects of Bile Acids on MUC2 Expression and Transcription}

SEG-1 treated with DCA, CDCA, and TCA. Viability of SEG-1 cells was not significantly affected by treatment for 24 hours with $200 \mu \mathrm{M}$ DCA (data not shown). The addition of DCA in 50-300 $\mu \mathrm{M}$ for 18 hours to SEG-1 increased MUC2 protein expression in a dose-dependent manner with a maximum increase of approximately 4fold (Fig. 1a). Different bile acids may have different biologic effects[22,23]. To examine the effects of different bile acids on MUC2 induction, we treated SEG-1 with DCA, CDCA, and TCA for 18 hours at a concentration of $100 \mu \mathrm{M}$. As shown in Figure $1 \mathrm{a}$, all three bile acids increased MUC2 protein expression, with DCA having the strongest effect.

To determine whether bile acids increase MUC2 promoter activity, we employed an MUC2 promoter luciferase construct, which contains a 2205-bp human MUC2 5'-flanking region fused to a luciferase reporter gene. After transient transfection, cells were treated with different concentrations of bile acid and luciferase activities were determined (Fig. 1b). DCA induced MUC2 promoter- 


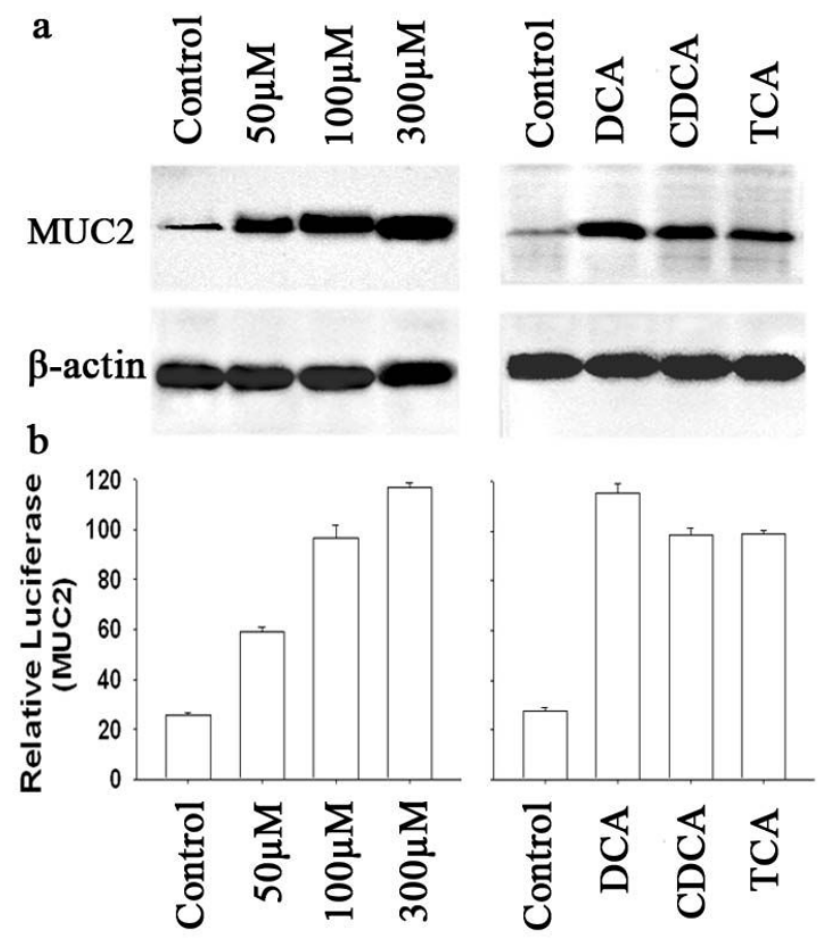

\section{Figure I}

Effect of bile acids on MUC2 expression. (a) SEG- I cells were treated for 18 hours with 50-300 $\mu$ M DCA (left) or with $100 \mu \mathrm{M}$ DCA, CDCA, or TCA (right). Total cellular protein was isolated and subjected to Western blotting for MUC2 and $\beta$-actin. (b) SEG-I cells were transfected with MUC2 promoter luciferase construct, then treated for 18 hours with 50-300 $\mu$ M DCA (left) or with $100 \mu \mathrm{M}$ DCA, CDCA, or TCA (right). Luciferase activity for the MUC2 reporter was measured and normalized to beta-galactosidase activity. Values shown represent the means \pm SD of triplicate experiments.

driven luciferase activities in a dose-dependent manner in SEG-1 cells, with a maximum 4-5 fold increase with 300 $\mu \mathrm{M}$ DCA. All tested bile acids induced MUC2 transcription activity to a varying extent at a concentration of 100 $\mu \mathrm{M}$ for 18 hours.

\section{Effects of Bile Acids on NF- $\kappa B$ Expression and Transcription}

We evaluated NF- $\kappa$ B p65 protein levels and gene transcription in the esophageal adenocarcinoma cell line. SEG-1 treated with DCA in 50-300 $\mu \mathrm{M}$ for 18 hours to SEG-1 increased NF- $\mathrm{B}$ p 65 protein expression in a dose dependent fashion with a maximum increase of approximately 5-fold (Fig. 2a).

To examine the effects of different bile acids on NF- $\kappa B$ induction, we treated SEG-1 with DCA, CDCA, and TCA for 18 hours at a concentration of $100 \mu \mathrm{M}$. As shown in

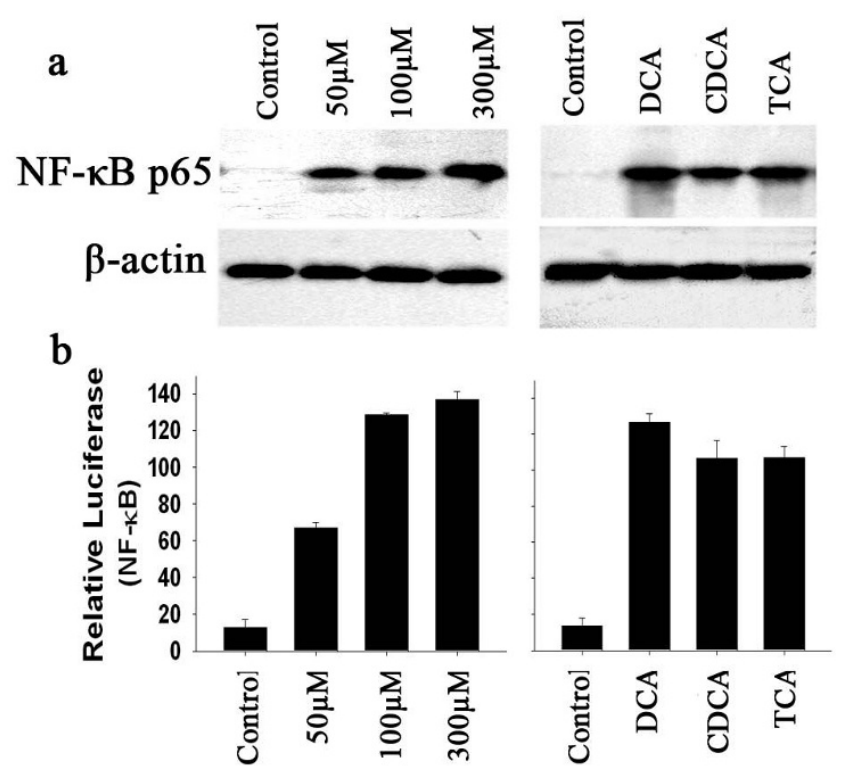

Figure 2

Effect of bile acids on Nuclear factor $-\kappa B$ (NF- $\kappa$ B) expression. (a) SEG-I cells were treated for 18 hours with 50-300 $\mathrm{M}$ DCA (left) or with $100 \mu$ M DCA, CDCA, or TCA (right). Cellular nuclear protein was subjected to Western blotting for NF- $\mathrm{B}$ p 65 and $\beta$-actin. (b) SEG-I cells were transfected with the NF- $\kappa B$ luciferase reporter plasmid, incubated for 24 hours, then treated for an additional 18 hours with $50-300 \mu \mathrm{M}$ DCA (left) or with $100 \mu \mathrm{M}$ DCA, CDCA, or TCA (right). Luciferase activity for NF- $\kappa B$ reporter plasmid was measured and normalized to beta-galactosidase activity. Values shown represent the means \pm SD of triplicate experiments.

Figure $2 \mathrm{a}$, all three bile acids increased NF- $\mathrm{B}$ p 65 protein expression, with DCA having the strongest effect.

To determine whether bile acids increase NF- $\kappa \mathrm{B}$ gene transcription, we employed a NF- $\kappa \mathrm{B}$ promoter luciferase construct, luciferase reporter gene driven by the $N F-\kappa B$ promoter, was transiently transfected into SEG-1. After 24 hours, the transfected cells were treated with increasing doses of DCA and with different bile acids in $100 \mu \mathrm{M}$ for 18 hours (Fig. 2b). DCA induced NF- $\kappa$ B promoter-driven luciferase activities in a dose dependent manner in SEG-1 cells, with a maximum 5-6 fold increase at a concentration of $300 \mu \mathrm{M}$. All tested bile acids induced NF- $\kappa \mathrm{B}$ luciferase activities to a varying extent at a concentration of $100 \mu \mathrm{M}$ for 18 hours, with DCA having the strongest effect (Fig. 2b), a result consistent with induction of MUC2 expression (Fig. 1b).

\section{Requirement of NF- $\kappa$ B for Induction of MUC2 by DCA}

Previous reports have suggested that NF- $\kappa \mathrm{B}$ is important in mediating bile acids signaling $[8,24]$. We therefore assessed the effect of NF- $\mathrm{KB}$ on expression of MUC2 
induced by DCA in SEG-1 esophageal adenocarcinoma cells. CAPE, an inhibitor of NF-kB activation, completely blocked the induction of MUC2 by DCA (Fig. 3). This result was confirmed using Western Blotting to estimate changes in protein levels (Fig. 3a) and RT-PCR in MUC2 and NF-кB p65 transcript levels (Fig. 3b). To determine whether CAPE blocked MUC2 promoter activity, we employed an MUC2 promoter luciferase construct, which contains a 2205-bp human MUC2 5'-flanking region fused to a luciferase reporter gene. After transient transfection, cells were treated with $100 \mu \mathrm{M}$ DCA for 18 hours and luciferase activities were determined (Fig. 3c). CAPE inhibite MUC2 promoter-driven luciferase activities in SEG-1 cells treated with DCA.

Whether NF-кB p65 involvement in DCA induced MUC2 activation, it was tested by transfection of NF-kB p65-specific siRNA into SEG-1 cells. Specific knockdown of endogenous NF- $\mathrm{kB}$ p 65 mRNA levels was observed (Fig. $4 \mathrm{a}, \mathrm{b})$, and the cells treated with NF- $\mathrm{kB}$ p 65 siRNA also showed potent suppression of DC-induced MUC2 activation detected with in MUC2 transcript levels and Western Blotting in protein levels (Fig. 4c). To determine whether NF-кB p65 siRNA blocked MUC2 gene transcription, we employed an MUC2 promoter luciferase construct. In NF$\kappa B$ p65 siRNA SEG-1 cells, after transient transfection MUC2 promoter luciferase reporter, cells were treated with $100 \mu \mathrm{M}$ DCA for 18 hours and luciferase activities were determined (Fig. 4c), NF- $\kappa B$ p65 siRNA inhibited MUC2 promoter-driven luciferase activities in SEG-1 cells treated with DCA. These results suggest that the activity of NF-kB p65 involved in DCA-induced activation of MUC2 in SEG-1 cells.

Although the precise mechanism by which aspirin inhibits esophageal tumorigenesis remains to be elucidated, it has been reported to inhibits NF-אB nuclear translocation in the esophageal squamous cell carcinoma cell line[25]. We examined the effect of aspirin, a potential chemopreventive agent in the prevention or treatment of esophageal cancer, on expression of MUC2 induced by DCA. In SEG1 esophageal adenocarcinoma cells treated with DCA $(100 \mu \mathrm{M})$ for 18 hours, the basal levels of MUC2 and NF$\kappa \mathrm{B}$ p65 proteins were decreased by treatment with 4 $\mathrm{mmol} / \mathrm{L}$ aspirin, there was also partial inhibition of the bile acid-dependent induction of MUC2 and NF-кB p65 (Fig. 5a). In assays of MUC2 transcription and NF- $\mathrm{kB}$ transcriptional activity, aspirin also had effect on basal activity, and inhibited the bile acid-dependent induction of MUC2 and NF-kB activity (Fig. 5b).

\section{Involvement of Protein Kinase $C$ but Not Protein Kinase $A$ in Induction of MUC2 by DCA}

It has been reported that bile acids activate PKC in esophageal adenocarcinoma cells[10,26]. Previous results have

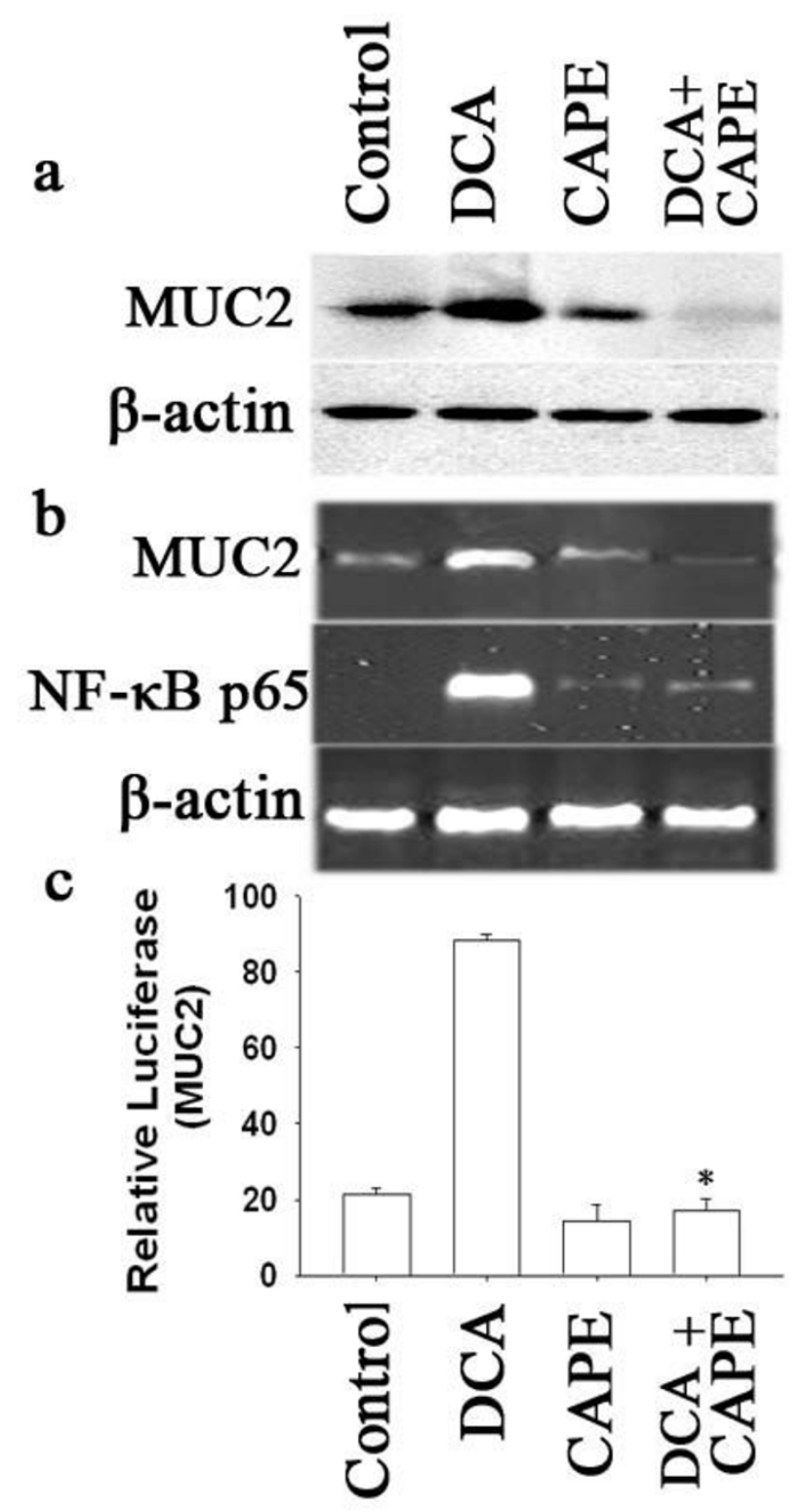

Figure 3

Effect of CAPE on expression of MUC2. SEG-I cells were pretreated with or without $10 \mu \mathrm{g} / \mathrm{ml}$ CAPE for $\mathrm{I} \mathrm{h}$ and then treated for 18 hours with or without $100 \mu$ M DCA. (a) Total cellular protein was subjected to Western blotting for MUC2 and $\beta$-actin. (b) The isolated RNA samples were analyzed by RT-PCR for MUC2, NF-kB p65 and $\beta$-actin. (c) SEGI cells were transfected with MUC2 promoter luciferase construct, then treated for 18 hours with or without $100 \mu \mathrm{M}$ DCA in the presence or absence of CAPE. Luciferase activity for MUC2 was measured and normalized to beta-galactosidase activity. (means \pm SD of triplicate assays, $* p<0.05$, for inhibition compared with assays without added inhibitor).

also shown that the PKC inducer PMA and bile acids increase MUC2 expression in colon carcinoma cell line, 


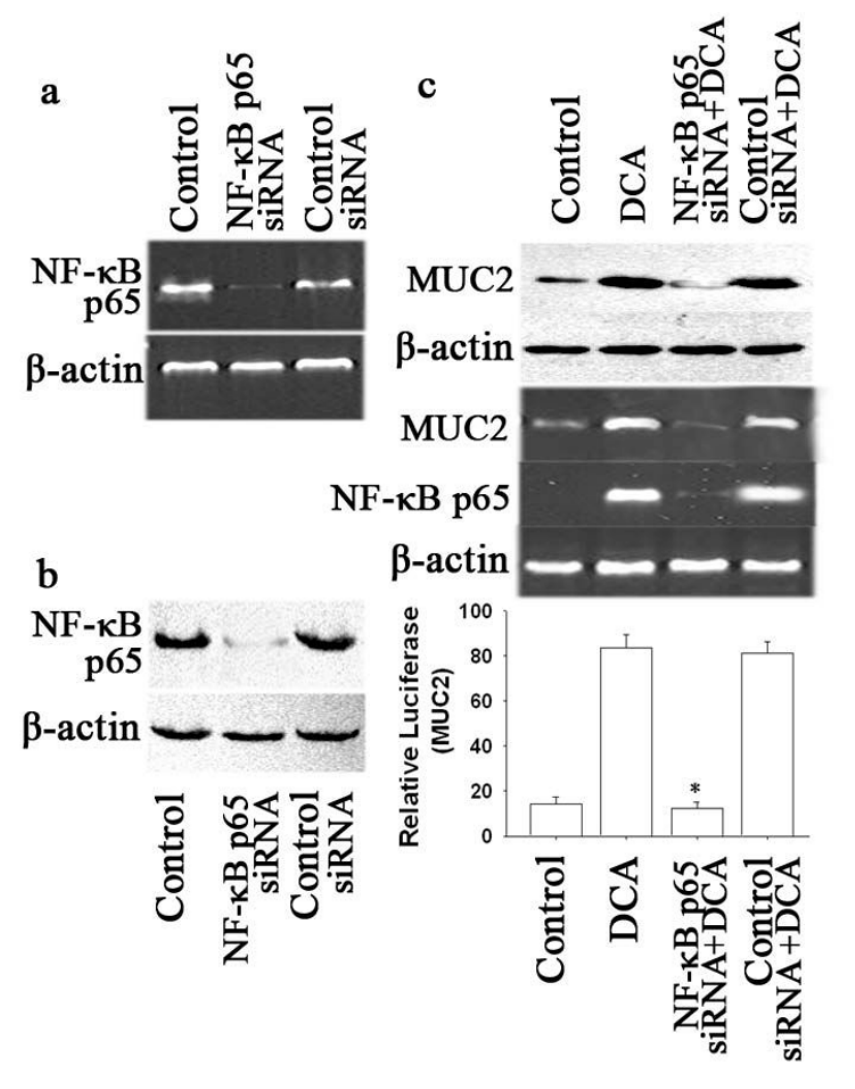

Figure 4

Effects of NF- $\kappa$ B p65 siRNA on expression of MUC2. SEG-I cells were transfected with Nuclear factor- $\kappa B$ (NF$\kappa B) ~ p 65$ siRNA, and its effect on NF- $\kappa B$ p 65 mRNA was analyzed using (a) RT-PCR, and (b) Western blotting. (c) Cells were treated with $100 \mu \mathrm{M}$ DCA for 18 hours after exposure to siRNA targeting NF- $\kappa B$ p65, (Upper panel) SEG-I cells lysates were analyzed in Western blotting for MUC2 and $\beta$ actin, (Middle panel) The isolated RNA samples were analyzed by RT-PCR for MUC2, NF- $\kappa$ B p65 and $\beta$-actin, (Lower panel) SEG-I cells were transfected with human MUC2 promoter luciferase construct, then treated for 18 hours with or without $100 \mu \mathrm{M}$ DCA after with or without exposure to siRNA targeting NF- $\kappa B$ p65. Luciferase activity for MUC2 was measured and normalized to beta-galactosidase activity. (means \pm SD of triplicate assays, $* p<0.05$, for NF- $\kappa B$ p 65 siRNA compared with assays without NF- $\kappa B$ p 65 siRNA).

and that this is prevented by the PKC inhibitor, calphostin $\mathrm{C}[27,28]$. However, it is unclear whether induction of MUC2 by bile acids is mediated by PKC in esophageal adenocarcinoma cells. When SEG-1 cells were treated with $6 \mathrm{nM}$ calphostin $\mathrm{C}$, there was almost complete inhibition of basal and bile acid-induced MUC2 protein and NF- $\kappa$ B p65 protein expression (Fig. 6a). This was accompanied by suppression of MUC2 transcription and of NF- $\kappa B$ transcriptional activity (Fig. 6b). These results indicate that
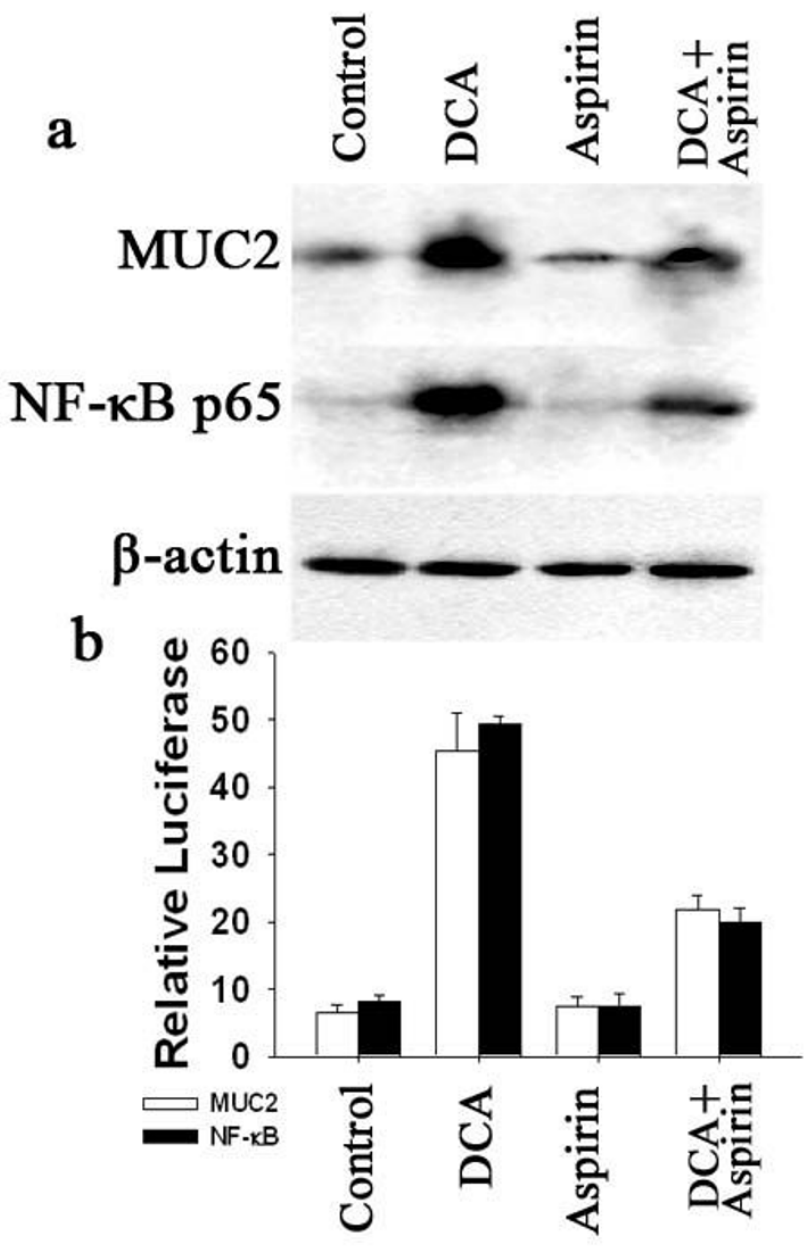

Figure 5

Effect of aspirin on MUC2 and Nuclear factor- $\kappa B$

(NF-KB) p65 expression. (a) SEG-I cells were treated for 18 hours with or without $100 \mu \mathrm{M}$ DCA in the presence or absence of $4 \mathrm{mmol} / \mathrm{L}$ aspirin. Total cellular and nuclear protein were subjected to Western blotting for MUC2, NF-кB p65, and $\beta$-actin. (b) SEG-I cells were transfected with human MUC2 promoter luciferase construct or NF- $\kappa B$ luciferase reporter plasmid, then treated for 18 hours with or without $100 \mu \mathrm{M}$ DCA in the presence or absence of $4 \mathrm{mmol} /$ $L$ aspirin. Luciferase activity for MUC2 or NF- $\kappa B$ was measured and normalized to beta-galactosidase activity. Values shown represent the means \pm SD of triplicate experiments.

PKC is involved in the NF- $\kappa \mathrm{B}$ dependent induction of MUC2 expression by DCA.

There has been reported that PKA is involved in bile acid induce MUC2 expression, and that this is prevented by the PKA inhibitor, H-8[28]. We also examined the effect on MUC2 induction by DCA of specific protein kinase inhibitor, H-8 (N-[2-(methylamino)ethyl]-5-isoquinolinesul- 


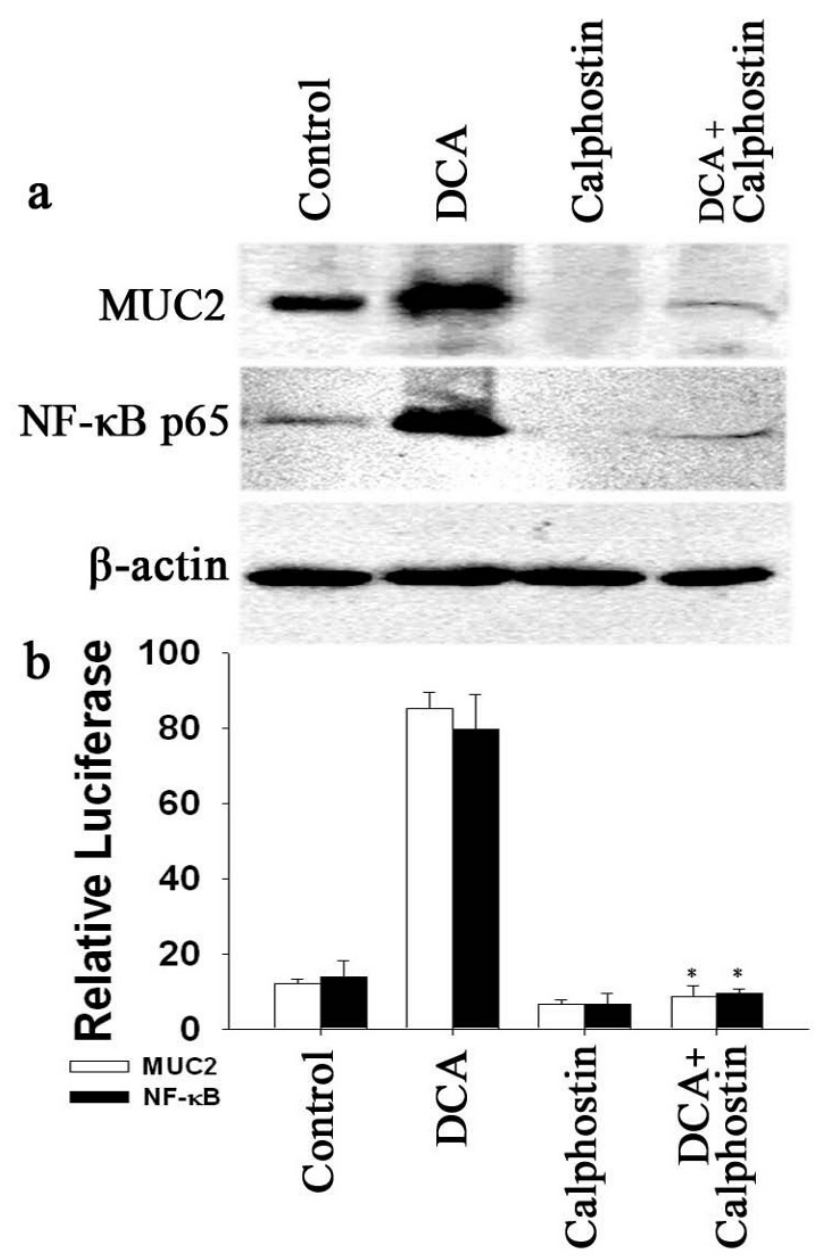

Figure 6

Effect of calphostin C on MUC2 and NF- $\kappa$ B p65

expression. SEG-I cells were treated for 18 hours with or without $100 \mu \mathrm{M}$ DCA in the presence or absence of $5 \mathrm{nM}$

calphostin C. (a) Total cellular and nuclear protein were subjected to Western blotting for MUC2, NF- $\mathrm{B} B \mathrm{p} 65$, and $\beta$ actin. (b) SEG-I cells were transfected with MUC2 promoter Luciferase construct or NF- $\kappa B$ Luciferase reporter plasmid, then treated for 18 hours with or without $100 \mu M$ DCA in the presence or absence of $5 \mathrm{nM}$ calphostin $C$. Luciferase activity for MUC2 or NF- $\mathrm{B}$ was measured and normalized to beta-galactosidase activity. (means \pm SD of triplicate assays, $* p<0.05$, for inhibition compared with assays without added inhibitor).

fonamide dihydrochloride). In our study, however, $\mathrm{H}-8$ did not inhibited levels of MUC2 protein and NF-кB p65 protein both in the presence and absence of DCA in SEG1 cells (Fig. 7a). There was also not a decrease in MUC2 transcription and in NF- $\mathrm{KB}$ transcriptional activity (Fig. $7 \mathrm{~b})$. These results suggest that the DCA-dependent induction of MUC2 depends on PKC but not PKA.

\section{Induction of MUC2 by DCA is not dependent of MAPK}

A previous study found that specific inhibitors of MAP kinase, U0126 and PD98059, inhibited the induction of MUC2 by bile acids[28]. To investigate the role of MAPK in the induction of MUC2 and NF-KB by DCA in esophageal adenocarcinoma cells, we examined phosphorylation of ERK1/2, JNK, P38 kinases and total ERK1/2, JNK, P38 kinases after treatment of SEG-1 cells with $100 \mu \mathrm{M}$ DCA for 18 hours. The DCA had effect on the levels of phosphorylated ERK1/2, JNK, and P-38 or total ERK1/2, JNK, and P-38 kinases (Fig. 8). To further investigate the effection of MAPK on the induction of MUC2 and NF- $\kappa B$, we

a
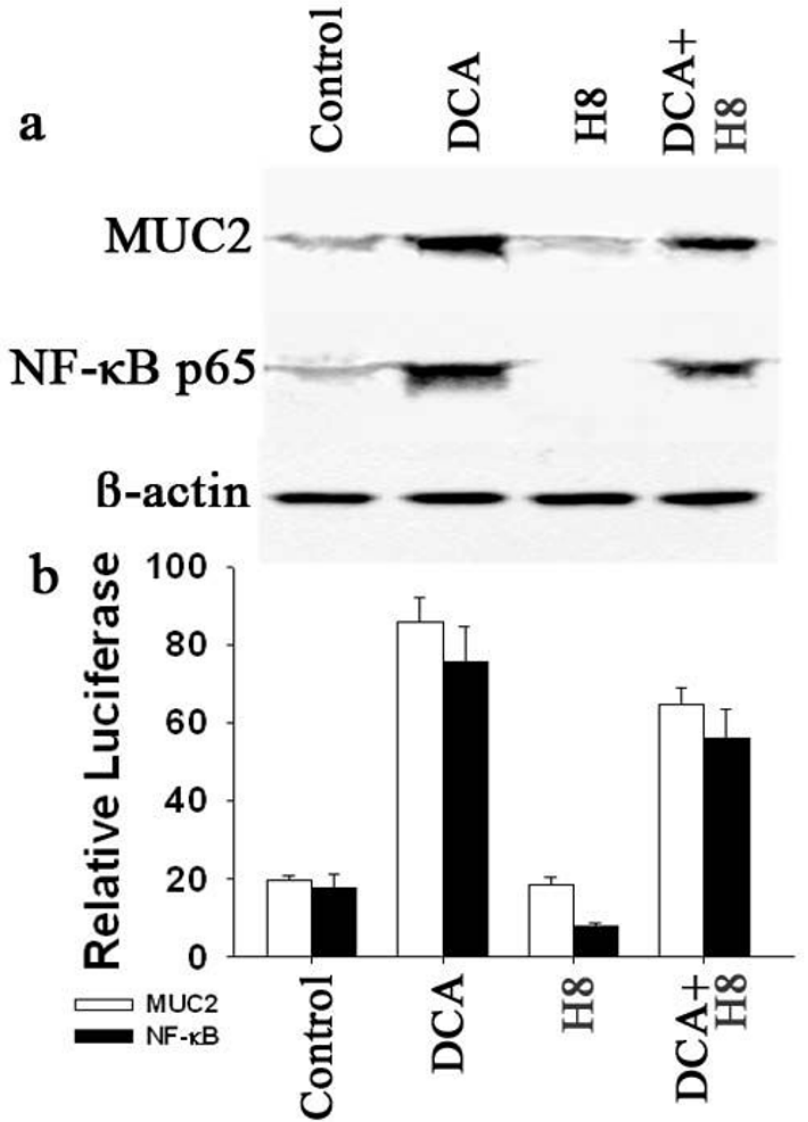

Figure 7

Effect of $\mathrm{H}-8$ on MUC2 and NF-Kb p65 expression. (a) SEG-I cells were treated for 18 hours with or without 100 $\mu M$ DCA in the presence or absence of $5 \mu \mathrm{M} \mathrm{H}-8$. Total cellular protein and nuclear protein were subjected to Western blotting for MUC2, NF- $k B$ p65, and $\beta$-actin. (b) SEG-I cells were transfected with the MUC2 promoter luciferase construct or the NF- $\kappa B$ luciferase reporter plasmid, then treated for 18 hours with or without $100 \mu M$ DCA in the presence or absence of $5 \mu \mathrm{M} \mathrm{H}-8$. Luciferase activity for MUC2 or NF$\kappa B$ was measured and normalized to beta-galactosidase activity. Values shown represent the mean and standard error of the mean of triplicate experiments. 
used U0126 and PD98059 to selectively block the activity of MAPK, we found that these inhibitors did not block the DCA-dependent increase in MUC2 protein and NF- $\mathrm{B}$ protein, although both U0126 and PD98059 did suppress phosphorylation of ERK1/2, JNK, and P38. These results suggest that expression of MUC2 and NF-KB treated with DCA is not dependent on MAPK in SEG-1.

\section{Discussion}

The effects of bile acids on mucin gene expression in esophageal adenocarcinoma cells have not been well studied. Bile acids has been reported to increase the secretion of MUC2 in esophageal cells[29], but MUC2 gene expression and the molecular events responsible for MUC2 gene expression were not studied in esophageal adenocarcinoma cells. In the current study, we find that bile acids increase MUC2 expression in SEG-1 esophageal

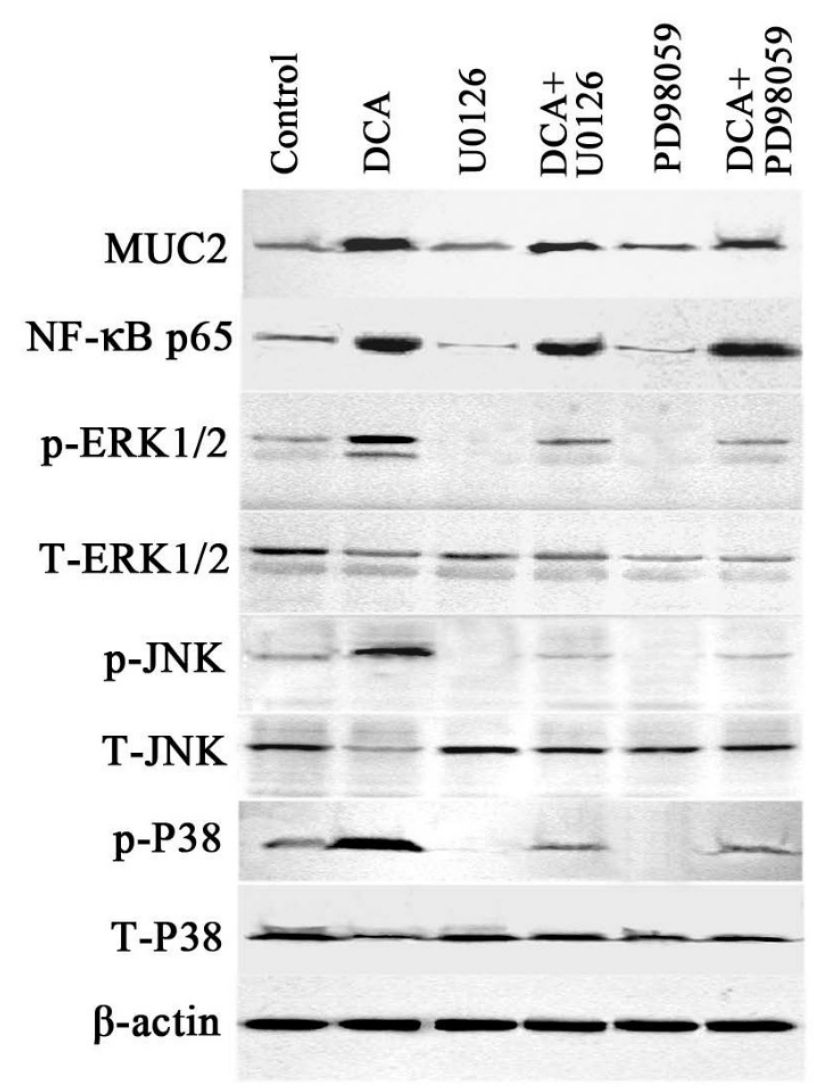

\section{Figure 8}

Effect of UOI 26 and PD98059 on MUC2 and NF- $\kappa B$ p65 expression. SEG-I cells were treated for 18 hours with or without $100 \mu \mathrm{M}$ DCA in the presence or absence of $8 \mu \mathrm{M}$ U0I26 and $60 \mu \mathrm{M}$ PD98059. Total cellular and nuclear protein were subjected to Western blotting for MUC2, NF$\kappa \mathrm{B}$ p65, phosphorylation of ERKI/2, JNK, P-38, and total ERKI/2, JNK, P-38 and $\beta$-actin. adenocarcinoma cells, and the transcriptional activity of MUC2 promoter reporter construct transiently transfected into SEG-1 was increased by DCA and other bile acids in a dose-dependent fashion, indicating that bile acidinduced MUC2 up-regulation occurs at the transcriptional level.

NF- $\kappa \mathrm{B}$ is an important transcription factor that mediates expression of multiple genes in important biologic processes including cell growth, apoptosis, and transformation [30-32]. We postulated that NF-кB could play a role in the induction of MUC2 by bile acids. Our data indicate that CAPE, an inhibitor of NF- $\mathrm{KB}$ translocation, it reduced endogenous as well as bile acid up-regulated MUC2 transcription, in addition NF- $\mathrm{\kappa B}$ expression and transcription activity coincided with MUC2 induction, and inhibition of NF- $\kappa \mathrm{B}$ expression and activity efficiently suppressed bile acid-mediated up-regulation of MUC2, indicating that NF- $\kappa \mathrm{B}$ is involved in MUC2 transcription induced by bile acid. Furthermore, it is confirmed by NF- $\mathrm{kB}$ p 65 siRNA can also blocked MUC2 expression induced by bile acid. Activation of NF- $\kappa B$ is mediated through phosphorylation, ubiquination, and subsequent degradation of

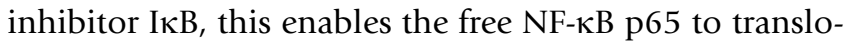
cate to the nucleus and activate target genes[33]. Our study shows that NF- $\mathrm{kB}$ p 65 expression can be induced by DCA, suggesting degradation of inhibitor I $\mathrm{B}$ may be involved in this pathway. Previous studies have indicated that NF- $\kappa B$ is involved in expression of MUC2[34,35], as the transcriptional competence of the NF- $\mathrm{KB}$ cis element was demonstrated containing the same region of the MUC2 promoter from bases 1528 to 1307 [27], implicating MUC2 promoter may be activated via expression of NF- $\kappa \mathrm{B}$ induced by bile acids. Other transcription factors that have been shown to regulate MUC2 expression in other contexts include SP-1, CDX-2, and GATA-5 [36-38]. It is likely that these transcription factors activities may be also required for MUC2 expression in esophageal adenocarcinoma cells, but this has not yet been established.

The transcriptional activity of NF- $\mathrm{KB}$ is also enhanced directly by phosphorylation at various sites on its subunits. The kinases responsible for these phosphorylations may include PKA, and PKC. Activation of PKC by bile acids is well documented, and may be one mechanism of bile acid induced carcinogenesis $[10,26]$. We found that the PKC inhibitor calphostin C strongly blocked NF- $\mathrm{KB}$ and MUC2 induction by DCA, indicating that PKC is involved in the bile acid-dependent induction of MUC2. PKA has been reported that it is involved in bile acids stimulate MUC2 expression, although the bile aciddependent induction of MUC2 depends less on PKA than on PKC[28]. However, our data indicated that the protein kinase A inhibitor, $\mathrm{H}-8$, is not effective in blocking bile acid dependent induction of MUC2 and NF- $\kappa \mathrm{B}$, suggest- 
ing expression of MUC2 induced by DCA independent on PKA. In contrast to previous work on MUC2 induction by PMA via the ERK cascade, we find that the induction of MUC2 by bile acid is independent of MAP kinases in SEG1 esophageal adenocarcinoma cells. Although treatment with DCA did affect the phosphorylation of ERK1/2, JNK, and P38 Kinase, U0126 and PD5089, inhibitors of MAP kinase, did not block MUC2 and NF- $\kappa$ B induction by DCA in SEG-1 cells, indicating MUC2 induction by DCA independent on the MAPK cascade.

\section{Conclusion}

We conclude that treatment of human esophageal adenocarcinoma cells with DCA, up regulates MUC2 transcription by activation of $\mathrm{NF}-\kappa \mathrm{B}$ via PKC but not PKA, independent of MAP kinase. The biologic consequences of the induction of MUC2 expression by bile acids are unclear. Further studies are needed to confirm that whether induction of MUC2 by bile acids can increase the invasion potential of cells and their metastatic potential in vitro and in vivo. A more detailed understanding of the precise mechanisms by which bile acids induce MUC2 could also facilitate the development of chemopreventive strategies to diminish the risk of carcinogenesis and metastasis, particularly in esophageal adenocarcinoma.

\section{Competing interests}

The authors declare that they have no competing interests.

\section{Authors' contributions}

JTW and JGo designed the study. JTW carried out the molecular genetic studies, the sequence alignment, designed primers, western blots, siRNA transfections and analysis, performed the statistical analysis, drafted and revised the manuscript. JGe carried out the data analysis, drafted and corrected the manuscript and participated in the molecular genetic studies, in the sequence alignment, primer design and the statistical analysis. YXS corrected the drafts. All authors read and approved the final manuscript.

\section{Acknowledgements}

We wish to thank Professor Lei Dong for his expert help in reviewing the manuscript and Dr. FuQuan Huo, Dr. WenBin Li, Dr. Wei Zhang for generous support of this project and RuiHong Zhang and MinGe Li for technical assistance.

\section{References}

I. Chinyama CN, Marshall RE, Owen WJ, Mason RC, Kothari D, Wilkinson ML, Sanderson JD: Expression of MUCI and MUC2 mucin gene products in Barrett's metaplasia, dysplasia and adenocarcinoma: an immunopathological study with clinical corre$\begin{array}{lll}\text { lation. } \quad H i s t o p a t h o l o g y & \text { 35(6):5 I7-524. }\end{array}$

2. Pera M, Pera M, de Bolos C, Brito MJ, Palacin A, Grande L, Cardesa $A$, Poulsom R: Duodenal-content reflux into the esophagus leads to expression of $\mathbf{C d x} 2$ and Muc2 in areas of squamous epithelium in rats. J Gastrointest Surg 2007, I I (7):869-874.
3. Tytgat KM, Buller HA, Opdam FJ, Kim YS, Einerhand AW, Dekker J: Biosynthesis of human colonic mucin: Muc2 is the prominent secretory mucin. Gastroenterology 1994, I07(5): | 352-I363.

4. Allen A, Hutton DA, Pearson JP: The MUC2 gene product: a human intestinal mucin. Int J Biochem Cell Biol 1998, 30(7):797-80I.

5. Warson C, Bovenkamp JH Van De, Korteland-Van Mal AM, Buller $\mathrm{HA}$, Einerhand AW, Ectors NL, Dekker J: Barrett's esophagus is characterized by expression of gastric-type mucins (MUC5AC, MUC6) and TFF peptides (TFFI and TFF2), but the risk of carcinoma development may be indicated by the intestinal-type mucin, MUC2. Hum Pathol 2002, 33(6):660-668.

6. Guillem P, Billeret V, Buisine MP, Flejou JF, Lecomte-Houcke M, Degand P, Aubert JP, Triboulet JP, Porchet N: Mucin gene expression and cell differentiation in human normal, premalignant and malignant esophagus. International journal of cancer 2000 , 88(6):856-86I.

7. Yen C-J, Izzo JG, Lee D-F, Guha S, Wei Y, Wu T-T, Chen C-T, Kuo $\mathrm{H}-\mathrm{P}$, Hsu J-M, Sun H-L, et al.: Bile Acid Exposure Up-regulates Tuberous Sclerosis Complex I/Mammalian Target of Rapamycin Pathway in Barrett's-Associated Esophageal Adenocarcinoma. Cancer Res 2008, 68(8):2632-2640.

8. Jenkins GJS, Cronin J, Alhamdani A, Rawat N, D'Souza F, Thomas T, Eltahir Z, Griffiths AP, Baxter JN: The bile acid deoxycholic acid has a non-linear dose response for DNA damage and possibly NF-\{kappa\}B activation in oesophageal cells, with a mechanism of action involving ROS. Mutagenesis 2008, 23(5):399-405.

9. Chen KH, Mukaisho K, Sugihara H, Araki Y, Yamamoto G, Hattori T: High animal-fat intake changes the bile-acid composition of bile juice and enhances the development of Barrett's esophagus and esophageal adenocarcinoma in a rat duodenal-contents reflux model. Cancer Sci 2007, 98(I I): I683-I688.

10. Song S, Guha S, Liu K, Buttar NS, Bresalier RS: COX-2 induction by unconjugated bile acids involves reactive oxygen speciesmediated signalling pathways in Barrett's oesophagus and oesophageal adenocarcinoma. Gut 2007, 56 (I I): I5 I 2-I52I.

II. Xia HH-X, Zhang ST, Lam SK, Lin MC-M, Kung HF, Wong BC-Y: Expression of macrophage migration inhibitory factor in esophageal squamous cell carcinoma and effects of bile acids and NSAIDs. Carcinogenesis 2005, 26(I): I I-I 5 .

12. Kazumori H, Ishihara S, Rumi MAK, Kadowaki Y, Kinoshita Y: Bile acids directly augment caudal related homeobox gene $\mathbf{C d x} 2$ expression in oesophageal keratinocytes in Barrett's epithelium. Gut 2006, 55(I): I6-25.

13. Roman S, Petre A, Thepot A, Hautefeuille A, Scoazec J-Y, Mion F, Hainaut $P$ : Downregulation of $p 63$ upon exposure to bile salts and acid in normal and cancer esophageal cells in culture. American journal of physiology 2007, 293(I):G45-53.

14. Mariette C, Perrais M, Leteurtre E, Jonckheere N, Hemon B, Pigny P, Batra S, Aubert JP, Triboulet JP, Van Seuningen I: Transcriptional regulation of human mucin MUC4 by bile acids in oesophageal cancer cells is promoter-dependent and involves activation of the phosphatidylinositol 3-kinase signalling pathway. The Biochemical journal 2004, 377(Pt 3):701-708.

15. Piessen G, Jonckheere N, Vincent A, Hemon B, Ducourouble MP, Copin MC, Mariette C, Van Seuningen I: Regulation of the human mucin MUC4 by taurodeoxycholic and taurochenodeoxycholic bile acids in oesophageal cancer cells is mediated by hepatocyte nuclear factor I alpha. The Biochemical journal 2007, 402(I):8I-9I.

16. Mariette C, Piessen G, Leteurtre E, Hemon B, Triboulet JP, Van Seuningen I: Activation of MUCI mucin expression by bile acids in human esophageal adenocarcinomatous cells and tissues is mediated by the phosphatidylinositol 3-kinase. Surgery 2008, I 43(I):58-7I.

17. Gum JR, Hicks JW, Kim YS: Identification and characterization of the MUC2 (human intestinal mucin) gene 5'-flanking region: promoter activity in cultured cells. The Biochemical journal I997, 325(Pt I):259-267.

18. Gray T, Nettesheim P, Basbaum C, Koo J: Regulation of mucin gene expression in human tracheobronchial epithelial cells by thyroid hormone. The Biochemical journal 2001, 353(Pt 3):727-734.

19. Mesquita P, Jonckheere N, Almeida R, Ducourouble M-P, Serpa J, Silva E, Pigny P, Silva FS, Reis C, Silberg D, et al.: Human MUC2 Mucin Gene Is Transcriptionally Regulated by Cdx Homeodomain 
Proteins in Gastrointestinal Carcinoma Cell Lines. J Biol Chem 2003, 278(5 I):5I549-5I556.

20. Schwenzer R, Siemienski K, Liptay S, Schubert G, Peters N, Scheurich $\mathrm{P}$, Schmid RM, Wajant $\mathrm{H}$ : The Human Tumor Necrosis Factor (TNF) Receptor-associated Factor I Gene (TRAFI) Is Upregulated by Cytokines of the TNF Ligand Family and Modulates TNF-induced Activation of NF-kappa B and c-Jun Nterminal Kinase. J Biol Chem I999, 274(27): 19368-19374.

21. Wajant H, Haas E, Schwenzer R, Muhlenbeck F, Kreuz S, Schubert G, Grell M, Smith C, Scheurich P: Inhibition of Death Receptormediated Gene Induction by a Cycloheximide-sensitive Factor Occurs at the Level of or Upstream of Fas-associated Death Domain Protein (FADD). I Biol Chem 2000, 275(32):24357-24366.

22. Mahmoud NN, Dannenberg AJ, Bilinski RT, Mestre JR, Chadburn A, Churchill M, Martucci C, Bertagnolli MM: Administration of an unconjugated bile acid increases duodenal tumors in a murine model of familial adenomatous polyposis. Carcinogenesis 1999, 20(2):299-303.

23. Wali RK, Khare S, Tretiakova M, Cohen G, Nguyen L, Hart J, Wang J, Wen M, Ramaswamy A, Joseph L, et al.: Ursodeoxycholic Acid and F6-D3 Inhibit Aberrant Crypt Proliferation in the Rat Azoxymethane Model of Colon Cancer: Roles of Cyclin DI and E-Cadherin. Cancer Epidemiol Biomarkers Prev 2002, II(I2): I653-1662.

24. Jenkins GJS, Harries K, Doak SH, Wilmes A, Griffiths AP, Baxter JN Parry JM: The bile acid deoxycholic acid (DCA) at neutral pH activates NF-\{kappa\}B and induces IL-8 expression in oesophageal cells in vitro. Carcinogenesis 2004, 25(3):3 I7-323.

25. Liu Jun-Feng, GGJPADG-JZS-WZT-NZB-ESQ-ZW: Aspirin induces apoptosis in oesophageal cancer cells by inhibiting the pathway of NF-kappaB downstream regulation of cyclooxygenase-2. ANZ journal of surgery 2005, 75(II): I0I I-1016.

26. Kaur BS, Triadafilopoulos G: Acid- and bile-induced PGE2 release and hyperproliferation in Barrett's esophagus are COX-2 and PKC-epsilon dependent. American journal of physiology 2002, 283(2):G327-334.

27. Lee H-W, Ahn D-H, Crawley SC, Li J-D, Gum JR, Basbaum CB, Fan NQ, Szymkowski DE, Han S-Y, Lee BH, et al: Phorbol I2-Myristate 13-Acetate Up-regulates the Transcription of MUC2 Intestinal Mucin via Ras, ERK, and NF-kappa B. J Biol Chem 2002, 277(36):32624-32631.

28. Song S, Byrd JC, Koo JS, Bresalier RS: Bile acids induce MUC2 overexpression in human colon carcinoma cells. Cancer 2005, 103(8): $|606-16| 4$

29. Hu Y, Jones C, Gellersen O, Williams VA, Watson TJ, Peters JH: Pathogenesis of Barrett Esophagus: Deoxycholic Acid UpRegulates Goblet-Specific Gene MUC2 in Concert With CDX2 in Human Esophageal Cells. Arch Surg 2007, I 42(6):540-545.

30. Li B, Cheung PY, Wang X, Tsao SW, Ling MT, Wong YC, Cheung ALM: Id-I activation of PI3K/Akt/NF\{kappa\}B signaling pathway and its significance in promoting survival of esophageal cancer cells. Carcinogenesis 2007, 28(I I):23 I3-2320.

31. Li J, Minnich DJ, Camp ER, Brank A, Mackay SL, Hochwald SN: Enhanced sensitivity to chemotherapy in esophageal cancer through inhibition of NF-kappaB. The Journal of surgical research 2006, I32(I):II2-120.

32. Abdel-Latif MM, O'Riordan J, Windle HJ, Carton E, Ravi N, Kelleher $\mathrm{D}$, Reynolds JV: NF-kappaB activation in esophageal adenocarcinoma: relationship to Barrett's metaplasia, survival, and response to neoadjuvant chemoradiotherapy. Annals of surgery 2004, 239(4):49I-500.

33. Karin M, Ben-Neriah Y: Phosphorylation Meets Ubiquitination: The Control of NF-KB Activity. Annual Review of Immunology 2000, I (8(I):62I-663.

34. Azzaroli F, Mehal W, Soroka C], Wang L, Lee J, Crispe N, Boyer JL: Ursodeoxycholic acid diminishes Fas-ligand-induced apoptosis in mouse hepatocytes. Hepatology (Baltimore, Md) 2002 36(I):49-54.

35. Ahn DH, Crawley SC, Hokari R, Kato S, Yang SC, Li JD, Kim YS: TNF-alpha activates MUC2 transcription via NF-kappaB but inhibits via JNK activation. Cell Physiol Biochem 2005, I5(I4):29-40

36. Perrais M, Pigny P, Copin M-C, Aubert J-P, Van Seuningen I: Induction of MUC2 and MUC5AC Mucins by Factors of the Epider- mal Growth Factor (EGF) Family Is Mediated by EGF Receptor/Ras/Raf/Extracellular Signal-regulated Kinase Cascade and Sp I*. J Biol Chem 2002, 277(35):32258-32267.

37. Yamamoto $\mathrm{H}$, Bai YQ, Yuasa Y: Homeodomain protein CDX2 regulates goblet-specific MUC2 gene expression. Biochem Biophys Res Commun 2003, 300(4):8I3-8I8.

38. Ren CY, Akiyama Y, Miyake S, Yuasa Y: Transcription factor GATA-5 selectively up-regulates mucin gene expression. J Cancer Res Clin Oncol 2004, I 30(5):245-252.

\section{Pre-publication history}

The pre-publication history for this paper can be accessed here:

http://www.biomedcentral.com/1471-2407/8/333/pre pub

Publish with Bio Med Central and every scientist can read your work free of charge

"BioMed Central will be the most significant development for disseminating the results of biomedical research in our lifetime. "

Sir Paul Nurse, Cancer Research UK

Your research papers will be:

- available free of charge to the entire biomedical community

- peer reviewed and published immediately upon acceptance

- cited in PubMed and archived on PubMed Central

- yours - you keep the copyright
BiolMedcentral 